University of Nebraska - Lincoln

DigitalCommons@University of Nebraska - Lincoln

Textile Society of America Symposium

Proceedings

Textile Society of America

$10-2020$

\title{
Colcha Circle: A Stitch in Northern New Mexico Culture
}

Olimpia Newman

new.olimpia@gmail.com

Rebecca Abrams

beccabrams@gmail.com

Follow this and additional works at: https://digitalcommons.unl.edu/tsaconf

Part of the Art and Materials Conservation Commons, Art Practice Commons, Fashion Design Commons, Fiber, Textile, and Weaving Arts Commons, Fine Arts Commons, and the Museum Studies Commons

Newman, Olimpia and Abrams, Rebecca, "Colcha Circle: A Stitch in Northern New Mexico Culture" (2020). Textile Society of America Symposium Proceedings. 1156.

https://digitalcommons.unl.edu/tsaconf/1156

This Article is brought to you for free and open access by the Textile Society of America at DigitalCommons@University of Nebraska - Lincoln. It has been accepted for inclusion in Textile Society of America Symposium Proceedings by an authorized administrator of DigitalCommons@University of Nebraska - Lincoln. 


\section{Colcha Circle: A Stitch in Northern New Mexico Culture}

Olimpia Newman \& Rebecca Abrams new.olimpia@gmail.com \& beccabrams@gmail.com

This documentary video entitled, Colcha Circle: A stitch in Northern New Mexico Culture was presented at the Textile Society of America's 2020 Symposium Hidden Stories/Human Lives captures a candid discussion among 11 colcha embroidery artists. Some of whom are entering their eighth and even ninth decade. They reveal what brought them to this art form, how it makes them feel, and what inspires them. The documentary is entertaining, filled with opinions coming straight from the artists, and illustrates inspiring designs and exquisite craftsmanship.

Early on, Julia Gómez sets the scene revealing to us that colcha embroidery "is a tribute to the women who came up the Camino Real that brought a little bit of beauty with the only things they had, which were the churro sheep... and a needle."

First and foremost, colcha embroidery is a folk art, characteristic of Northern New Mexico and Southern Colorado history, traditions, and cultural expression.

The term, colcha, translates from Spanish as quilt or bedcovering. The colcha stitch comprises a long laid stitch secured to the ground cloth by self-couched stitches; it is worked with a single thread and needle. The colcha stitch is similar to Bokhara, Roumanian, and Kloster couching stitches, but it is employed differently for free-form surface design effects. Designs typically featured stylized flowers, vines, leaves, animals and Moorish-influenced arabesques.

During the Spanish colonial era, the hardy Navajo-Churro sheep's wool was spun into yarn and dyed with local plants indigenous to the high desert, as well as with cochineal and with indigo that had to be imported from the far-flung Spanish Empire. These handspun yarns were made into a loosely woven cloth, termed sabanilla, derived from the Spanish word sábana (sheet or shroud), which adorned beds, windows, and ceilings as well as home and church altars. The stitch itself mended many a torn shirt or pants, and also added layers of additional coverage and design to the cloth, thus increasing the weight of the base cloth two or even threefold, and rendering it warm.

Today, colcha embroidery artists continue to practice this art form in private homes and small circles. Many follow ancestral designs and make embroidery pieces that often depict early designs, images from nature, and religious motifs. A few choose to address social issues or dare to break with conventions of the Hispanic culture. Some of these artists teach throughout their community, whereas others are introduced by family members, an expression of their local culture.

A few times, colcha embroidery was introduced to a community as a result of economic development programs, as was the case in the San Luis Valley, Colorado. Repeatedly, colcha embroidery helped to document the history, life, and faith of the people of the Pecos Valley that now adorns 265 feet of embroidered panels throughout the Roman Catholic Church of Our Lady of Guadalupe in Villanueva, New Mexico. 
Colcha embroidery pieces can be admired in many New Mexico museums or purchased from the artists during exhibitions. Embroidery circles still meet regularly in Albuquerque at the National Hispanic Cultural Center, in Santa Fe at the Museum of Spanish Colonial Arts, and Martinez Hacienda in Taos. These embroidered textiles win prizes at the Spanish Colonial Arts Society's annual Spanish Market in Santa Fe, the biennial Albuquerque Fiber Fiesta, and the biennial colcha exhibit in Española. One can also appreciate the work during demonstrations at Las Golondrinas, the living history museum south of Santa Fe. Surprisingly, colcha embroidery is rarely part of local textile art exhibits or competitions.

Colcha embroidery has been documented in various books, most extensively by Nora Fisher in an entire chapter in the Spanish Textile Tradition of New Mexico and Colorado and the revised edition Rio Grande Textiles. Also in Nancy C. Benson's New Mexico Colcha Club: Spanish Colonial embroidery \& the women who saved it, and most recently by Suzanne P. MacAulay's Stitching Rites: colcha embroidery along the Northern Rio Grande. Multiple small publications offer how-to instructions and patterns, and occasional articles in the local press draw attention to exhibitions. Still, the documentation does not include prominent colcha artists' accounts from whom they learned their skill and, in turn, whom they taught, or discuss the stitch variations and contemporary innovation in colcha embroidery designs.

Therefore, the Colcha Circle documentary addresses this void and allows artists to express their personal opinion. The video was produced by the Española Valley Fiber Arts Center (EVFAC) and can be freely viewed by copying this link into your browser. www.vimeo.com/292758833

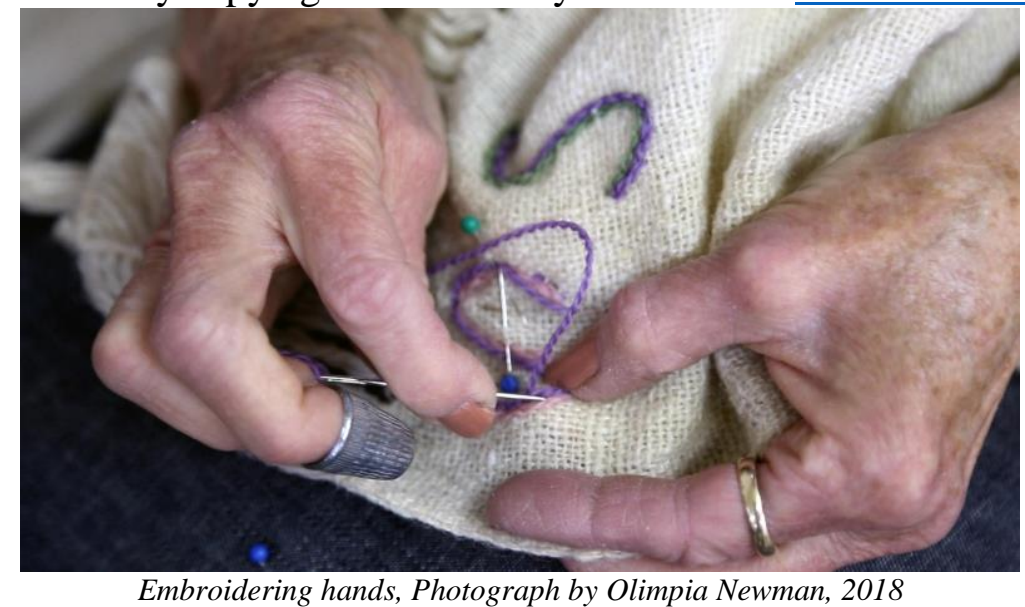

There remains more to the Colcha Circle than the video was able to reveal. So we decided to organize a virtual exhibition of colcha embroidery artwork featuring many more artists than those featured in the documentary. Respecting New Mexico's Covid-19 regulations, we picked up each artist's work, arranged photography sessions from a distance, and conducted interviews over the phone. It was a worthwhile effort that complements the documentary and enriches this overview as well, offering colcha embroidery the exposure it merits.

The next section includes personal biographies and beautiful portraits of eight of the artists who were part of the Colcha Circle. Besides, we added one more artist, Beatrice Maestas Sandoval, who could not participate in person on the filming day. Beatrice was very important to many of the "bordadoras"; she taught many of them how to shear the sheep, spin the Navajo-Churro wool, 
weave the sabanilla, gather the dye plants and even dye the yarns. Her influence can be heard repeatedly in the documentary, and that is why we were delighted to interview her in Las Vegas, New Mexico, with one of her exquisite pieces.

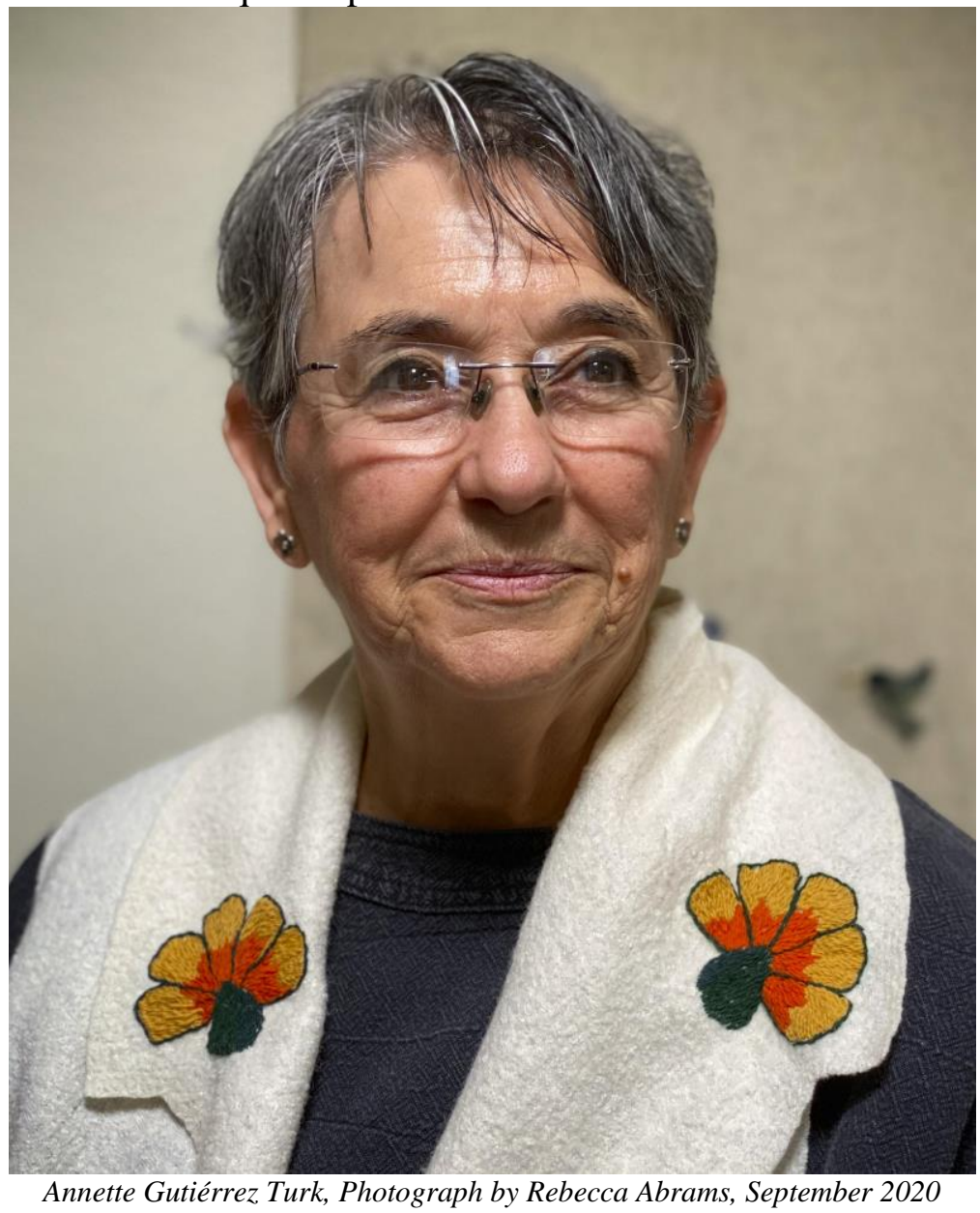

Annette Gutiérrez Turk (b. 1944, Albuquerque, New Mexico) is a 16th generation New Mexican who was raised and lives in Albuquerque. Annette fell in love with colcha embroidery in 1997, when she was introduced to the stitch at the National Hispanic Cultural Center by Mónica Sosaya-Halford.

In 2009 at El Rancho de las Golondrinas, a living history museum south of Santa Fe, Beatrice Maestas Sandoval mentored Annette, teaching her to spin her own yarn with the malacate and spinning wheel, dye her own Navajo-Churro wool with native plant materials, and weave her own base cloth.

Annette is an active member of the Sandia Mountains Chapter of the Embroiderers Guild of America. She teaches colcha embroidery locally, regionally, and nationally.

She regularly exhibits her work in the annual juried Spanish Market, where she is honored to have been awarded 1st place in the Collaboration and Utilitarian categories in 2016 with woodworker, Fredrico Prudencío. Their intricate sewing box has a permanent home in the collection of the Spanish Colonial Arts Society in Santa Fe, New Mexico. Annette has exhibited 
as far away as China, where she represented the United States in the United Nations-sponsored International Folk Crafts and Cultural Products Exposition in 2015, 2016, and 2017. Her work is in the collection of the Guizhou Ethnical Culture Museum, Guizhou, China, and many private collections.

Annette loves flowers and birds and incorporates them into her pieces, which she describes as innovative within tradition. Annette uses colcha embroidery to create everything from bracelets and necklaces to elaborate garments.

Best of all for Annette, she says, "You can't worry about anything when doing colcha embroidery. It just calms you down. It's very therapeutic."

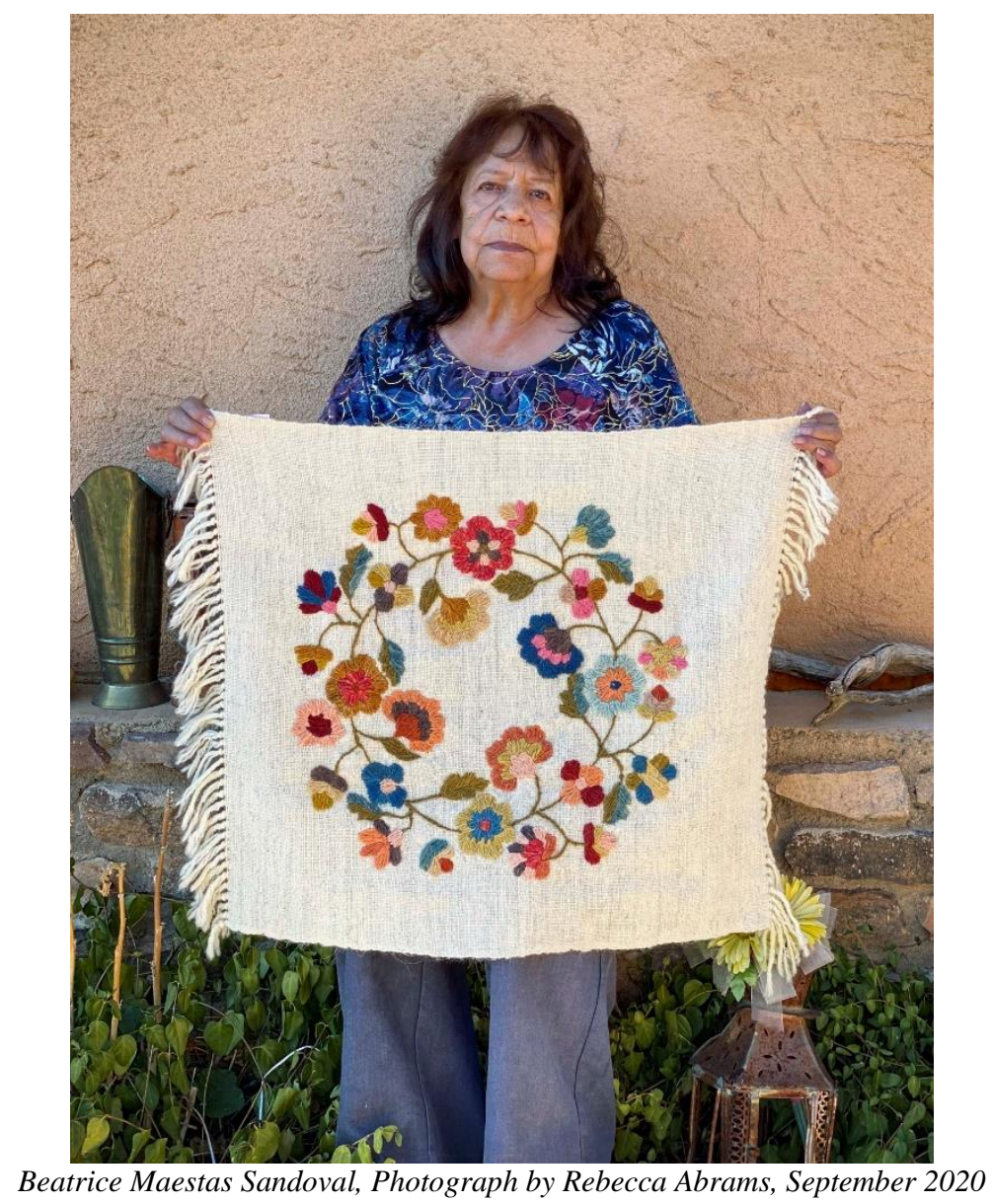

Beatrice Maestas Sandoval (born 1947, Las Vegas, New Mexico) was raised alongside six siblings in an adobe home built by their father in Las Vegas, New Mexico. While growing up, Beatrice heard stories about her great-grandmother, Martita Baca, a weaver whose portrait hangs in the family home, where Beatrice now resides. These stories inspired Beatrice to pursue weaving and, subsequently, to learn colcha embroidery and other traditional Spanish colonial arts such as tinwork. 
Beatrice feels deeply connected to the Land of Enchantment and its many colors, which inspire her to use natural resources yielded by the land to make her own dyes, spin her own yarn, and weave her own sabanilla cloth from the fleece of local Navajo-Churro sheep. Beatrice is a beloved teacher and was the longtime Curator of Textiles and Volunteer Coordinator at El Rancho de las Golondrinas (1995-2009).

For two decades she participated in Spanish Market, where she was awarded the Grand Prize, Best of Show, as well as numerous other awards. Among many honors, Piecework Magazine named her Needleworker of the Year in 2005, and in 2012 she was awarded the Centennial Artist of the Year at the Fiber Arts Festival, Albuquerque, New Mexico.

Beatrice prides herself on the care and love she puts into creating each individual piece from start to finish. She produces all her work using natural materials created by hand and from her heart and even built her own loom with her longtime partner, George Ulibarri, so as to create the exact brake system that works best for weaving sabanilla.

Beatrice derives pleasure knowing that her process holds true to the original "tradiciones" and that she is helping to preserve her Spanish heritage.

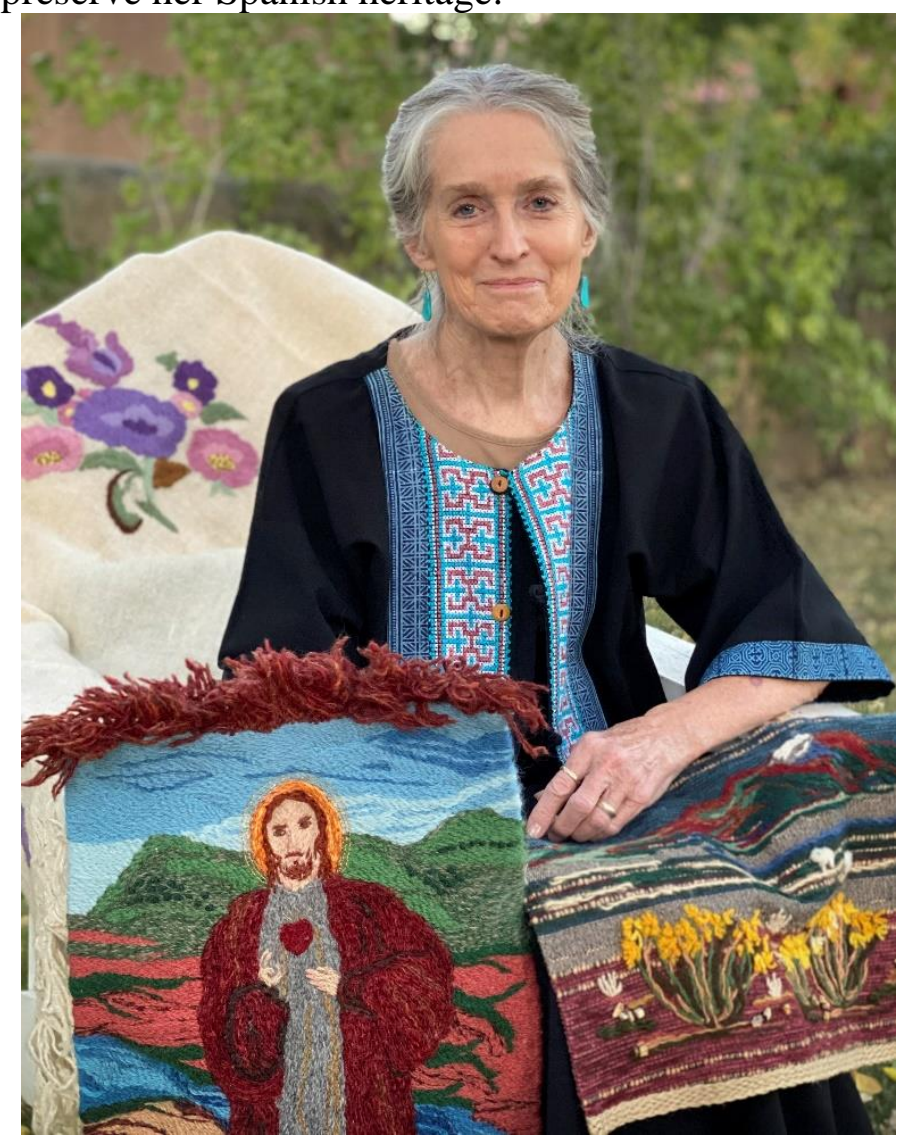

Connie Fernández, Photograph by Rebecca Abrams, September 2020

Connie Fernández (born in New Haven, Connecticut) was raised in a multi-racial, multi-ethnic, and multi-religious family in Oregon and rural San Fernando Valley, California. Connie has resided in Taos, New Mexico, for more than thirty years following many years in Colorado. She 
retired in 2014 after a 43-year career teaching inner-city high school students in South-Central Los Angeles, juveniles in a maximum security correctional facility in Colorado, and middle schoolers in Taos.

Growing up, Connie was inspired to pursue needlework by her grandmothers. Years later, upon moving to Taos, she began to explore colcha embroidery on her own and had the good fortune to meet Josephine Lobato and Rita Lobato Crespín at the Fort Garland Museum and Cultural Center in southern Colorado. They validated her work and encouraged her to pursue colcha embroidery as an art form.

Connie has studied with Mónica Sosaya-Halford and Beatrice Maestas Sandoval. She enjoys stitching alongside her fellow "bordadoras," many of whom join her in a monthly colcha embroidery gathering at Martinez Hacienda, a Taos "living museum" that was first built during the Spanish colonial era and is now listed on the National Register of Historic Places.

Connie uses natural Navajo-Churro wool and traditional materials, often embroidering on sabanilla woven by Annette Gutiérrez Turk and using yarn dyed by Glenna Dean, yet her themes are often contemporary. Many of her pieces address political and social themes, such as genocide in Rwanda and the tragic suffering of women in Juárez, Mexico.

Connie teaches workshops and classes; she also lectures and demonstrates throughout northern New Mexico, where her work is widely exhibited. Connie embroidered the altar cloth for La Capilla de San Antonio de Padua - La Loma, Taos. She rarely sells her work, and instead prefers to donate to various causes.

Connie's fervent desire is "to see colcha embroidery embraced by the younger generation, treasured and revered in its historical form, and appreciated as it continues to reflect a living art form." She is a believer in lifelong learning and cherishes the sharing of ideas among her fellow colcha embroiderers. 


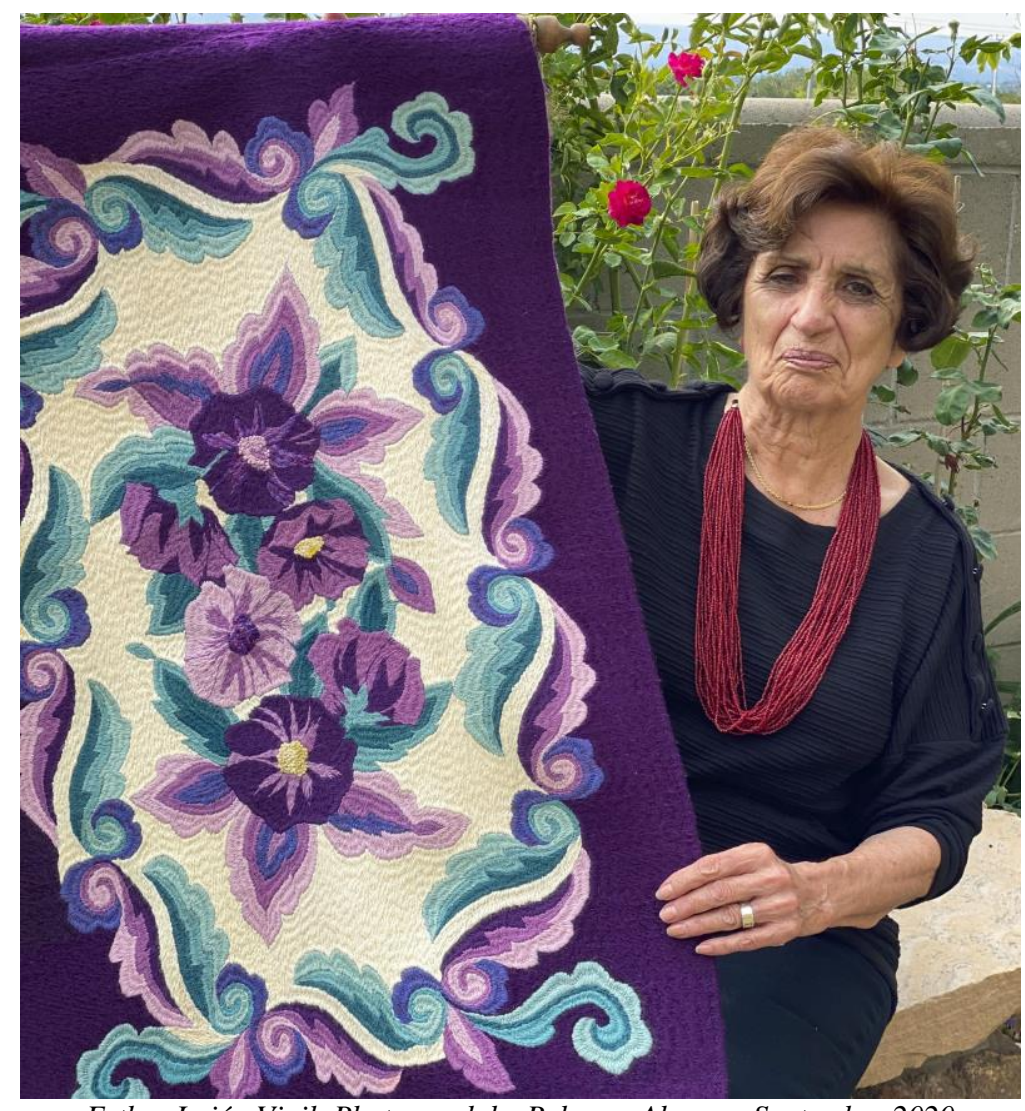

Esther Luján Vigil, Photograph by Rebecca Abrams, September 2020

Esther Luján Vigil (born 1933, San Pedro, Española, New Mexico) is a colcha embroidery artist and historian of colcha embroidery who has authored and self-published Colcha Embroidery: Book I and Colcha Embroidery: Book II, in May 2006 and May 2010 respectively. Esther was raised in San Pedro, and educated in Española, Los Alamos, and Santa Fe, New Mexico.

In 1954 Esther married José Vigil, and together they raised four children in Albuquerque, New Mexico. They have had the pleasure of watching seven grandchildren grow up nearby. Esther's grandson, Gregory (b. 1988), is learning colcha embroidery from her, just as she learned from her mother, Maria Teófila Ortiz Luján (1895-1994), who played a seminal role in both preserving and reviving colcha embroidery in the Española Valley and beyond.

Esther's goal is to preserve her culture and heritage through colcha embroidery, just as her mother and her mother's friends did beginning 1928 when they founded the colcha embroidery group, Arte Antiguo. ${ }^{1}$

Esther has followed her mother in several important ways, including using commercial yarn and backing, the primary materials available in the 1930s and 40s in the Española Valley and surrounding area. Also like her mother, who was married in 1920, Esther's wedding ceremony was performed by Father Salvador from the church in Santa Cruz, New Mexico.

\footnotetext{
${ }^{1}$ Nancy C. Benson, New Mexico Colcha Club
} 
In the 1980s Esther honored the importance of the church by embroidering its altarpiece. Esther prides herself on having 40-60 needle penetrations per square inch and on the back of her pieces being as beautiful as the front.

"The beauty that you have within you is what you're putting onto the cloth with your hands." Esther Luján Vigil.

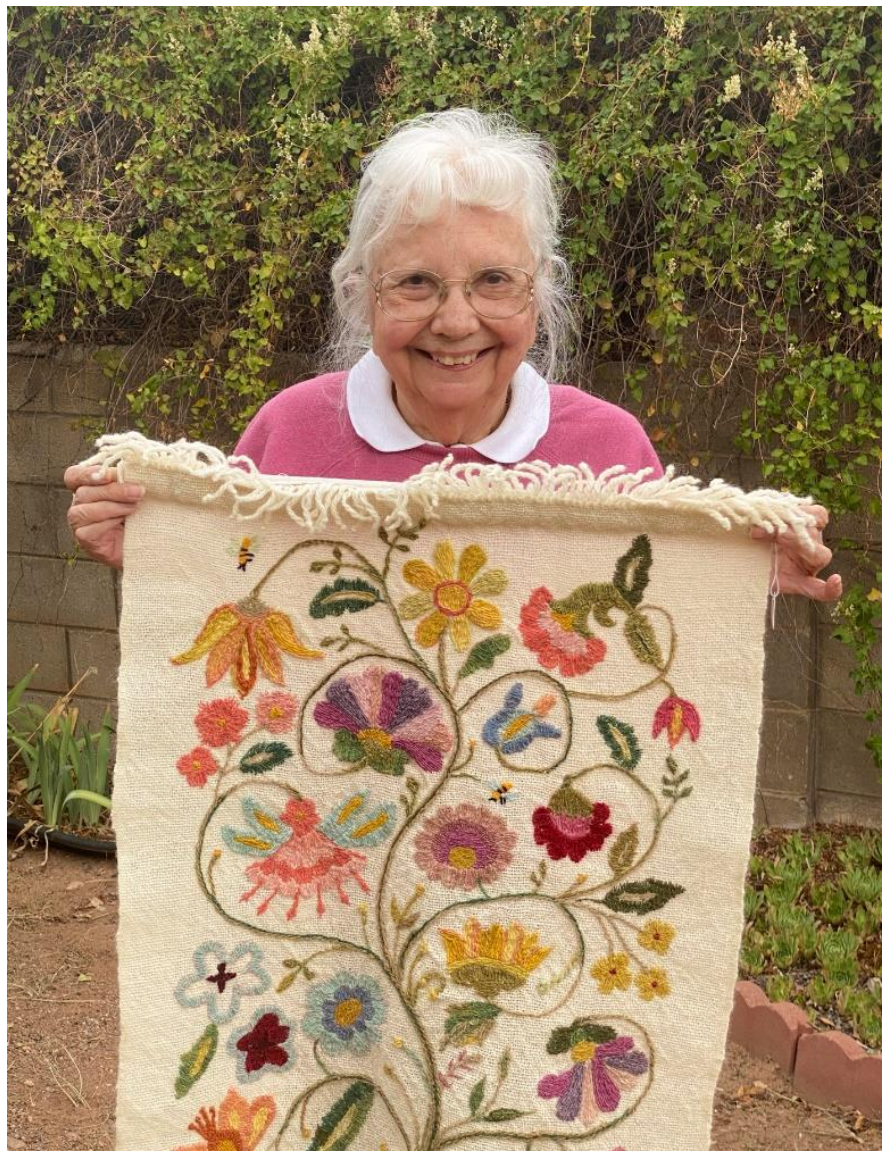

Irene Brandtner de Martínez, Photograph by Rebecca Abrams, September 2020

Irene Brandtner de Martínez (b. 1932, El Paso, Texas) was raised in Bayard, New Mexico, the eldest of five siblings. She is a lifelong embroiderer who has concentrated on colcha embroidery since 1992, the year of her retirement as a longtime librarian in the Santa Fe public schools and Santa Fe Arts Commission employee. Irene studied colcha embroidery with Mónica SosayaHalford at Santa Fe Community College more than two decades ago and learned to weave and spin from Beatrice Maestas Sandoval at El Rancho de las Golondrinas in 2005.

Irene focuses on designing and stitching her works and jokingly refers to herself as "The Queen of Tiny Stitches" because she uses single-ply Paternayan (Persian) wool on linen. For more than fifty years Irene has enjoyed genealogy research. A distinguishing feature of her work is the use of colonial motifs, such as a vase with flowers alongside a dove. This reflects her intense interest in the history of the US Southwest and of New Spain (New Mexico) and her mother's connection to New Mexico's first colonial period. 
In addition to colcha embroidery, Irene also creates religious and secular watercolor, oil, acrylic, and egg tempera paintings in both traditional and contemporary styles. One of Irene's gifts to the local colcha embroidery community is her love of design and her generosity in sharing her graphic skills; she regularly stencils designs onto fabric for her fellow colcha embroiderers so they have a design on which to stitch. Irene is a longtime volunteer at the Museum of Spanish Colonial Arts and at El Rancho de las Golondrinas.

She is also a world traveler who has visited China, where she delighted in seeing fine silk embroiderers at work. Her work has been exhibited in numerous juried shows including Santa Fe's Spanish Market, where she has been juried into both the Colcha Embroidery and Retablo categories. Irene has done extensive research on the history of European embroidered book covers. This led to her embroidering a book cover for "Santos and Saints: The Religious Folk Art of Hispanic New Mexico" for which she won the first place blue ribbon and was awarded the Hispanic Heritage Award in 2018.

The following year, Irene again won the first place blue ribbon for a second book cover - this one covering a large notebook containing 25 different colonial motifs (flowers, birds, animals, etc.) on individual pieces of 8" by 9" sabanilla. Irene's book covers perfectly synthesize her interest in historical research and colcha embroidery.

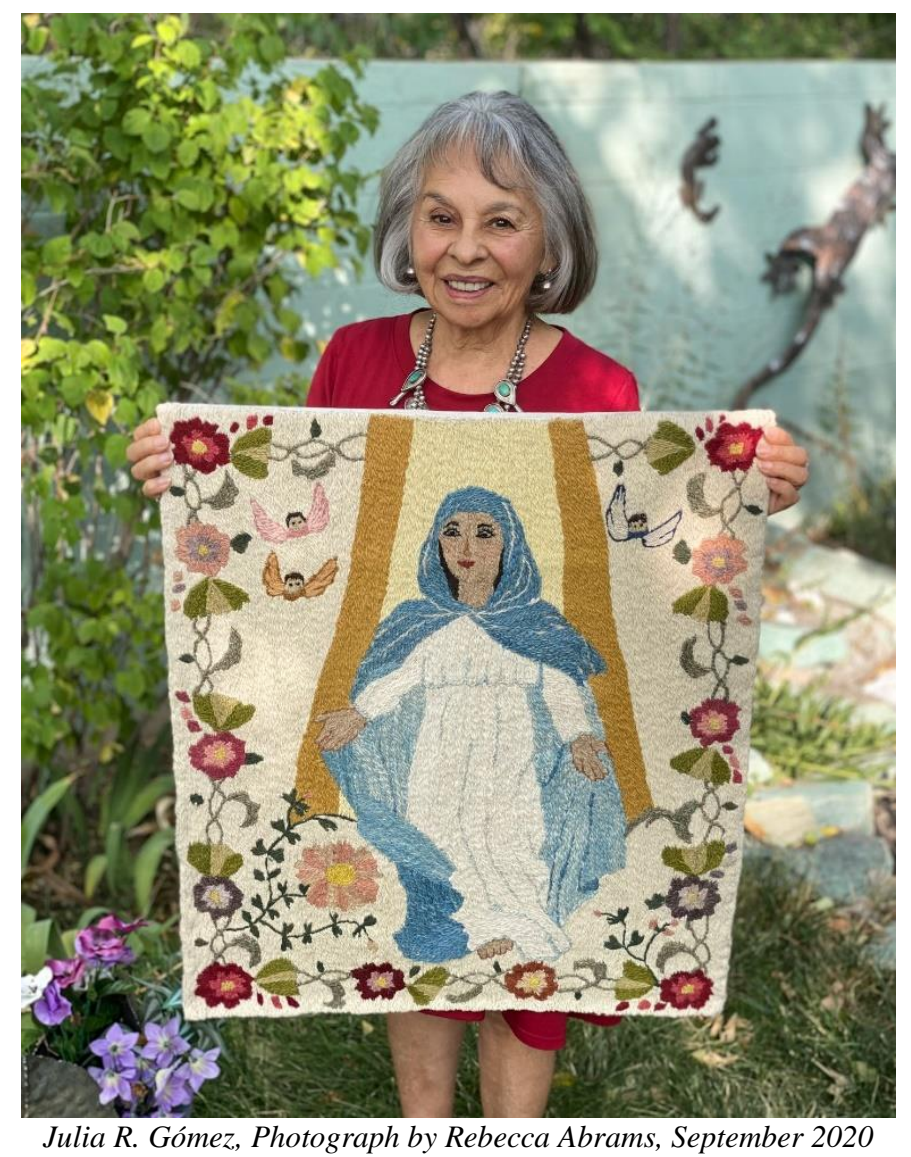


Julia R. Gómez (born 1941, Madrid, New Mexico) was first exposed to colcha embroidery by her mentor, Mónica Sosaya-Halford, in the 1970s. She later learned to weave at El Rancho de las Golondrinas, where master weaver, Beatrice Maestas Sandoval, instructed Julia on working with natural dyes and handspun yarn so as to employ many of the same methods that the Spanish settlers of northern New Mexico used in colonial times. Julia is among the few artists who spins Churro wool and weaves sabanilla backing cloth made during the colonial period in this far northern province of New Spain.

Since retiring in 2002, following a 36-year career teaching home economics in the Santa Fe public schools, Julia has devoted herself to colcha embroidery. She has participated in Spanish Market for eighteen years. Among many honors, she won Best of Show in 2010. Her piece, "Tree of Life," was chosen in 2015 for the Spanish Market poster, and now the original piece resides at the Museum of Spanish Colonial Arts (MOSCA), where she teaches monthly.

Julia teaches whenever and wherever she can, including at the Santa Fe Senior Center, through a great from MOSCA, and at El Rancho de las Golondrinas, where Julia loves teaching children about hand-dying, hand-spinning, and hand-weaving. Several of Julia's young students have participated in Youth Spanish Market, one even winning Blue Ribbon for colcha embroidery in 2019.

Julia has been instrumental in founding colcha embroidery clubs in Taos and Albuquerque, New Mexico, and reviving a group in San Luis, Colorado. In October 2020, Julia presented her work in the online conference, The Inspired Needle, hosted by Winterthur Museum, Wilmington, Delaware, and at the biannual symposium of the Textile Society of America.

Julia has demonstrated colcha embroidery as far away as China, where in 2015 she received an Honorary Credential and Master Artist Recognition. Julia graduated from Santa Fe High School and New Mexico State University and did her graduate work at the University of New Mexico in education. She has one daughter, Sarahmaria, who lives and works in China, a country that Julia has visited five times. 


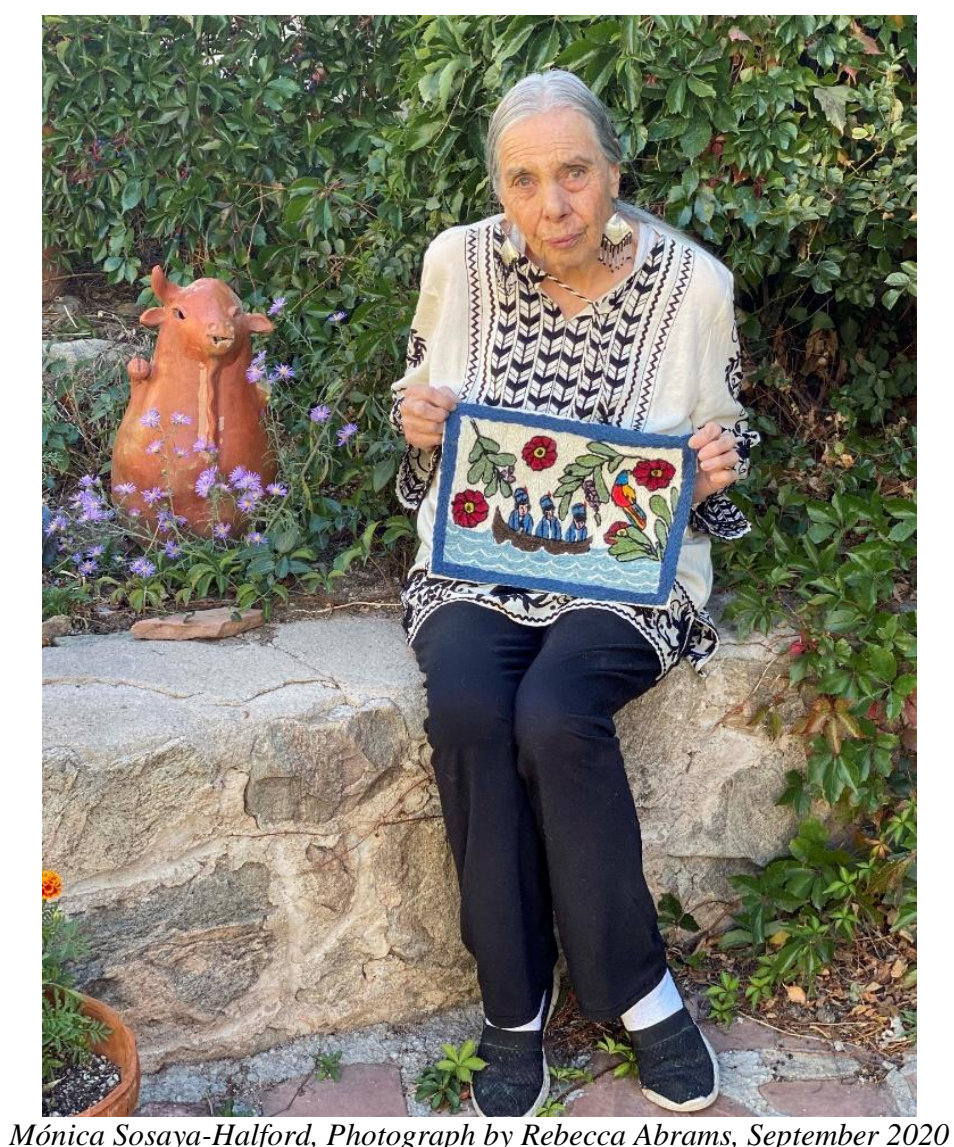

Mónica Sosaya-Halford (b. 1931, Santa Fe, New Mexico), the eighth and last child of Augustine and Victoria Sosaya, grew up in a home built by her father on what is now Sosaya Lane. Her mother's family, the Roybals, descend from the original settlers who arrived in 1598 in New Mexico (then known as New Spain) with Don Juan de Oñate. Mónica has enjoyed making art since her earliest days at Loretto Academy Santa Fe and Wood Gormley Elementary School, where her painted Easter Bunny was singled out as meriting recognition in the Second Grade.

While a student at Santa Fe High School, Mónica studied with Jozef Barkos (1891-1977), one of Santa Fe's noted Los Cinco Pintores. She later studied Interior Design at California College of Art and Crafts (CCAC). While serving in the Navy in Alameda, California, in the 1950s, Mónica received her first official commission - sketches of ballerinas for a commanding officer's daughter.

In the 1980s Mónica learned colcha embroidery from Maria Hesch (1909-1994), a Santa Fe artist renowned for her folk paintings and intricate colcha embroidery designs. In turn, Mónica has gone on to become a beloved teacher to her own students at Santa Fe Community College, the Museum of International Folk Art, and the National Hispanic Cultural Center in Albuquerque. Her colcha embroidery students include Connie Fernández of Taos, Annette Gutiérrez Turk of Albuquerque, and Julia Gómez and Kay Lewis of Santa Fe, among many others.

Mónica prefers to work with soft fabrics, such as linens, and finds canvas and even sabanilla more difficult to stitch with a needle. For Mónica, "the softer, the better." Mónica enjoys telling 
Biblical stories with her needle and yarn and every piece includes telltale details such as San Rafael holding his fish, Saint Michael with his foot squashing a serpent representing the devil, and Santa Mónica with her wine.

Mónica's work is in many private and corporate collections and in museums including the Museum of International Folk Art, the Museum of Spanish Colonial Art, and the National Hispanic Cultural Center. Mónica's work has been selected three times as the poster art for Spanish Market, where she has had Booth \#4 every year since 1979. She has been honored with the Mayor's Award for Excellence in the Arts, the Governor's Award for the Arts, the Spanish Colonial Arts Society's Masters Award for Lifetime Achievement, and in May 2017 she was honored as a Santa Fe Living Treasure.

Mónica is a tireless volunteer, active family member, and hostess galore who says, "If you can laugh at yourself you can get along pretty well."

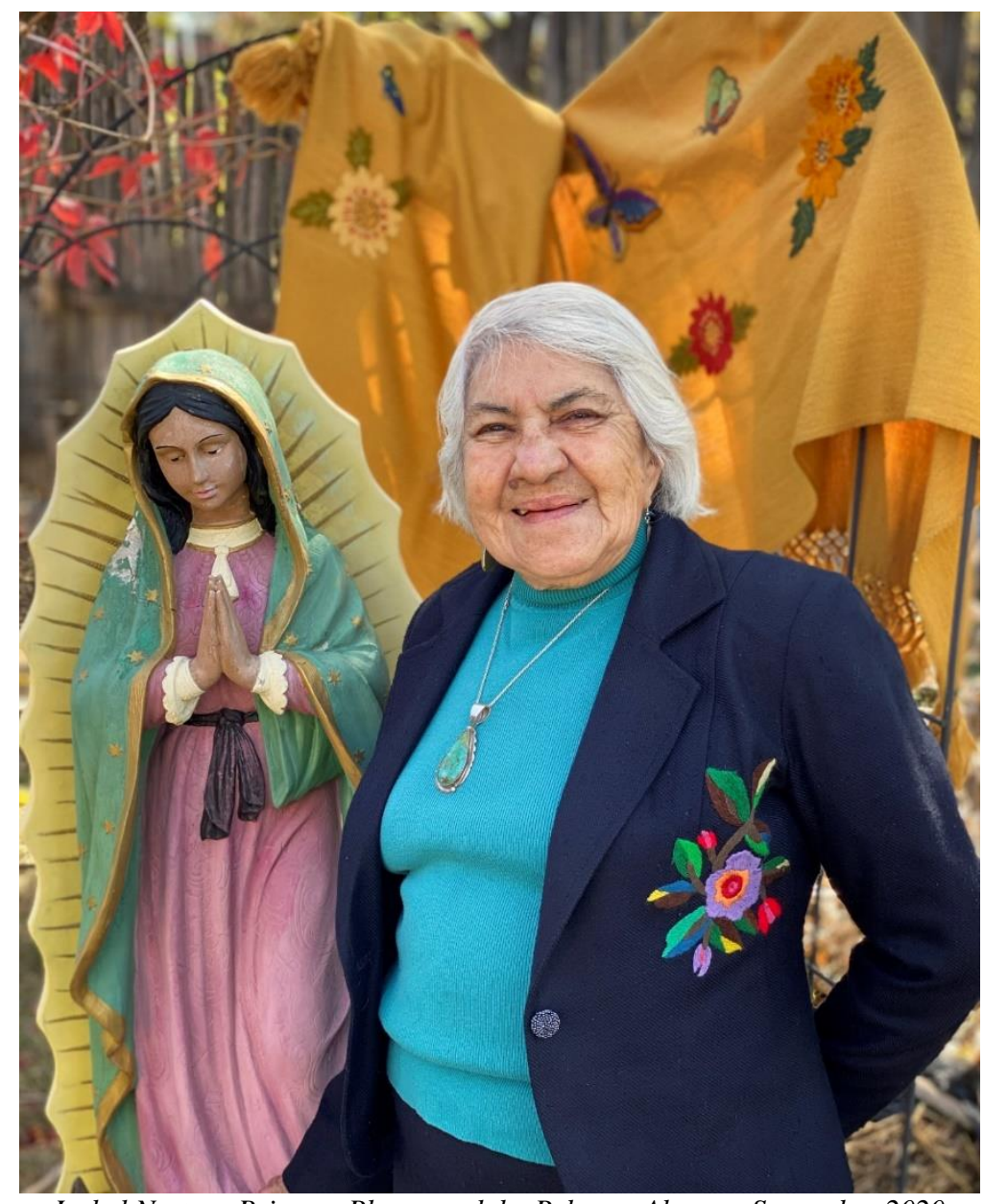

Isabel Nestora Bringas, Photograph by Rebecca Abrams, September 2020

Isabel Nestora Bringas (born 1934, Taos, New Mexico) was born and raised in the house that her parents built in Taos in 1920. As a child she loved playing in her uncle's cornfield next door and learning to sew on her grandmother's old Singer treadle sewing machine. While in high 
school Nestora lived with her older sister, Guadalupe "Lupita," in Albuquerque, where she subsequently attended the University of New Mexico and met "the love of [her] life."

She raised her brood of fifteen children while living in Gary, Indiana, and the Chicago suburbs, during which years she worked as a seamstress primarily doing alterations. Nestora learned to take apart, alter, and then return to pristine form the finely-tailored clothing of her customers; this, in turn, exponentially improved her sewing skills. In 1998, after nearly four decades in the midwest, Nestora returned to live full-time in Taos.

Not only did she reunite with her childhood friend and next door neighbor, Joan, but in 2000 she joined the "Taoseñas," a social group that originally formed in the early 1930s with the aim of encouraging local Spanish-speaking women to practice their English language skills. Nestora was introduced to colcha embroidery at Taoseñas gatherings.

This quickly led to her developing a passion for using the colcha stitch to embroider onto items such as her custom-made and custom-tailored suits and onto purses and shawls of her own design. Frequent motifs are sunflowers, butterflies, and hummingbirds.

Nestora's pride and joy is the altar cloth she and five other women made that is on permanent display at Martinez Hacienda, Taos. Each of the six women completed an identically designed pattern of flowers embroidered in primary colors such as red and blue on an off-white linen and silk background fabric. Nestora joined the six pieces together and created a backing for the altar cloth.

Nestora is an active member of a colcha embroidery group that meets monthly at Martinez Hacienda to socialize and stitch together. She finds colcha embroidery to be relaxing and meditative. Nestora refers to colcha embroidery as "chicken soup for the soul." 


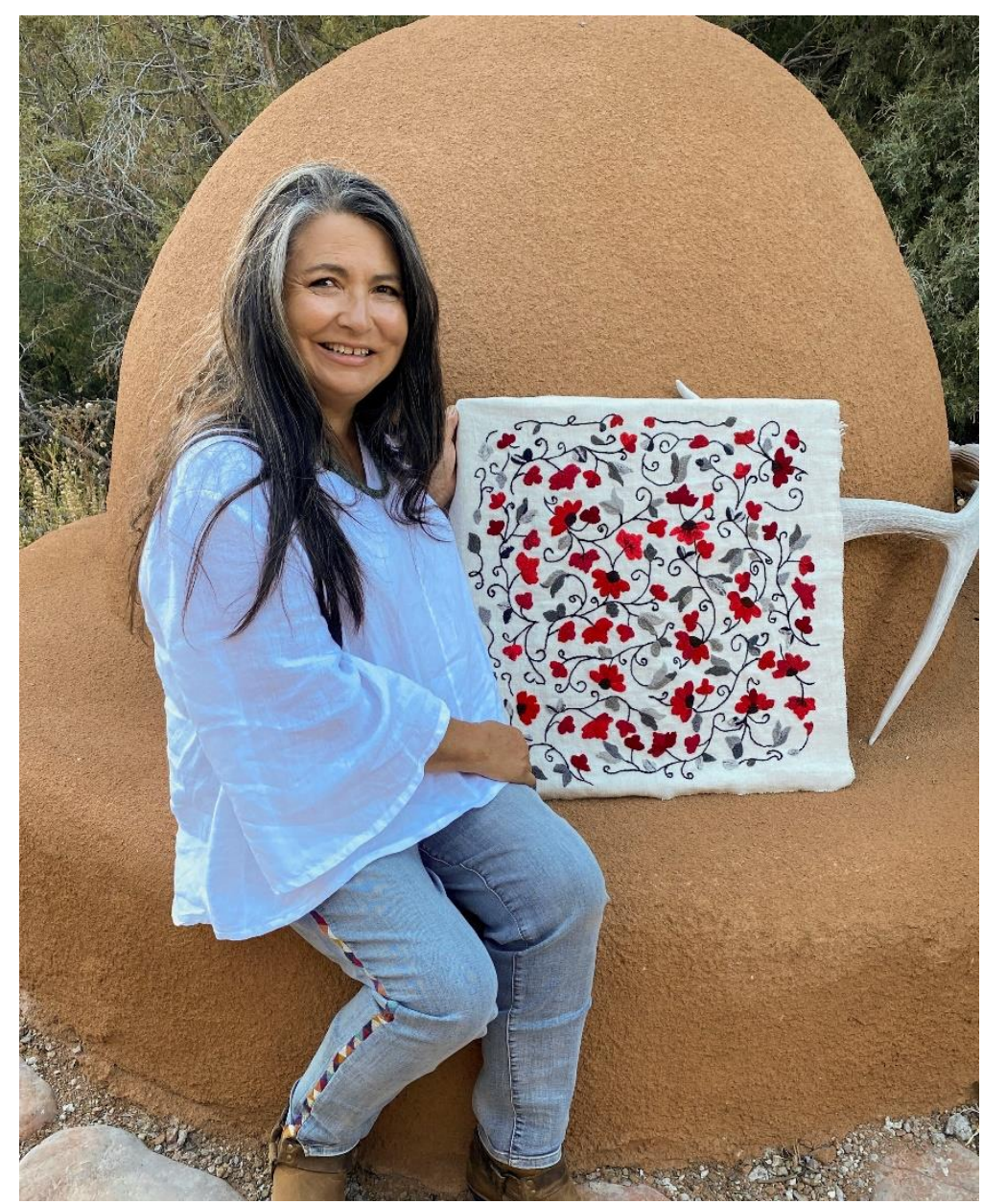

Sharon Arellano, Photograph by Rebecca Abrams, September 2020

Sharon Arellano (b. 1958, Taos, New Mexico) is the eldest of four daughters raised in Peñasco on the scenic High Road to Taos. She received her Bachelor of Social Work from New Mexico Highlands University, Las Vegas, New Mexico. Following a twenty-five year career as a juvenile probation and parole officer with the New Mexico Children, Youth, and Families Department, Sharon retired in 2011 and now focuses her energy on creative pursuits.

Sharon is a firm believer that creativity is good for one's mental health and enjoys working in many forms including clay, tin, and nearly all types of fiber arts. Sharon works in a large sunfilled studio in her home and bakes her clay pieces in an adobe horno oven built by her husband and friends that resides outside her front door. Sharon was first exposed to colcha embroidery in 2012 in a class taught by Beatrice Maestas Sandoval at Art for the Heart Gallery in Peñasco.

In 2016 she learned to weave sabanilla during a 6-month class taught by Karen Martinez, a 7th generation weaver in Chimayó. Like many colcha embroiderers, Sharon creates from the heart, and seldom with the intention of selling her work. She enjoys using the traditional colcha embroidery stitch in nontraditional ways. For instance, when Sharon first retired from professional life, she took apart and embroidered on the clothes she no longer needed for a life in the public eye. 
Sharon embroiders everything from hatbands to shawls and even, since Covid-19, personal protective masks. She has explored the nude female form in colcha embroidery. Sharon enjoys participating in the monthly gathering of needleworkers at Martinez Hacienda in Taos, where she cherishes the encouragement, expertise, and camaraderie of Connie Fernández and others.

She lives in rural New Mexico, where she says one must "stay busy and be creative." Sharon and her husband, David, have one son and one granddaughter who live in Albuquerque. Their home is filled with Sharon's creations, including large framed colcha embroidery for which David creates the woodwork and numerous smaller ceramic pieces.

\section{$\underline{\text { Bibliography }}$}

Benson, Nancy C. New Mexico Colcha Club: Spanish Colonial Embroidery \& the Women Who Saved It. Albuquerque, New Mexico: Museum of New Mexico Press, First Edition, October 6, 2008.

Espinosa, Carmen G. New Mexico Colonial Embroidery. Los Lunas, New Mexico: facsimile reprint by Simmons \& Simmons Books of the edition published by the New Mexico Department of Vocational Education, May, 1935.

Fisher, Nora. Spanish Textile Tradition of New Mexico and Colorado. Albuquerque, New Mexico: Museum of New Mexico Press, 1979.

Fisher, Nora. Rio Grande Textiles. Albuquerque, New Mexico: Museum of New Mexico Press; First edition, August, 1994.

MacAulay, Suzanne P. Stitching Rites: Colcha Embroidery along the Northern Rio Grande. Tucson, Arizona: University of Arizona Press, Second Edition, August 1, 2000.

Pettit, Michael. Artists of New Mexico Traditions - The National Heritage Fellows. Albuquerque, New Mexico: Museum of New Mexico Press, 2012. Features - Frances Varos Graves, NEA Fellow 1994, Pages 83-92.

Schueler, Karen. Colcha Embroidery Handbook. Albuquerque, New Mexico: Sandia Mountains Chapter, Embroiderers Guild of America, Inc., 1995, revised 1997.

Vigil, Esther L., Colcha Embroidery. Albuquerque, New Mexico: Self-published, May 2006.

Vigil, Esther L., Colcha Embroidery: Book II. Albuquerque, New Mexico: Self-published, May 2010 . 